\title{
An Analysis of the Main Difficulties in Chinese Kindergarten Bilingual Education
}

\author{
Wei Na \\ Lecturer, School of Foreign languages \\ China West Normal University, Nanchong, Sichuan, China \\ babylala@vip.sina.com
}

\begin{abstract}
An upsurge in English-Chinese bilingual instruction programs has witnessed the main adoption of English language classroom teaching in different areas in China. With an increasing awareness of the importance of English language use, bilingual teaching has been advocated in preschool education. This article focuses on the analysis of the major difficulties in Chinese kindergarten bilingual education, and possible solutions are given so as to throw light on bilingual teaching in China to some degree.
\end{abstract}

Keywords: bilingual teaching, difficulties, kindergarten education

\section{INTRODUCTION}

Global school is a new concept which is commonly accepted by people all around the world. It emphasizes the crucial role English language is playing in school education. Thus, bilingual education is becoming indispensable these days, especially in China. Bilingual teaching has already been implemented in some of Chinese primary schools and middle schools, but the result is not so satisfying. Even though most of the Chinese students have studied English for a decade or more, they can not communicate in English well with each other or with foreigners from English-speaking countries. Therefore, bilingual education in child stage has gradually been paid much attention to since it is the critical period for children to acquire a foreign language before their primary schools according to Lenneberg(1967) and Montessori(1965) both of whom have advocated better language acquisition occurs in childhood. English course has been offered in most Chinese kindergartens in recent years, and a series of activities have been promoted for encouraging English learning in kindergarten. However, difficulties still remain at the same time for English teachers in Chinese kindergarten which will be discussed in details in the following.

\section{A BRIEF INTRODUCTION OF BILINGUAL EDUCATION}

\subsection{Definition}

Bilingual teaching is a newly promoted teaching style, which indicates that the students can gradually grasp a foreign language or their second language in a kind of language environment which is designed to facilitate education of non-English speaking students by teaching them in their native language as well as in English.

In everyday use the word bilingual usually means a person who speaks, reads, or understands two languages equally well (a balanced bilingual), but a bilingual person usually has a better knowledge of one language than of the other. For example, he/she may: 1) be able to read and write in only one language; 2 ) use each language in different types of situation, e.g. one language 
at home and the other at work; 3) use each language for different communicative purposes, e.g. one language for talking about school life and the other for talking about personal feeling. (Richards, Platt \& Weber, 1985)

It is mainly because of the Critical Period Hypothesis that bilingual education becomes popular in preschool education. It was first introduced by Montreal neurologist Wilder Penfield and Lamar Roberts(1959) and was promoted then by Eric Lenneberg(1967). He believes that human language learning is greatly influenced by biological factors and there is a critical period which begins in the first two years of puberty till the end of it. If language acquisition does not occur during this period, it will be more difficult afterwards and full mastery of the language cannot be achieved.

\subsection{Types of Bilingual Education}

There are three main types of bilingual education according to E-Power(2016) : 1) Immersion methodology. It refers to the main use of one school language which might not be the children's home language; 2) Maintenance bilingual education. It means school teachers will gradually adopt the school language for teaching some subjects but use the home language to teach others; 3) Transitional bilingual education. This type indicates teachers would teach all the subjects in children's home language at the very beginning but later adopt the school language as the single language to go on with the teaching. And among those three main modes of bilingual teaching: transitional, maintenance and enrichment (E-Power, 2016), maintenance bilingual education is generally adopted in most Chinese schools, which encourages the students to maintain their native language in order to strengthen their social identity on one hand, and help them understand the subjects and the communication on the other.

\section{Bilingual Education in Chinese Kindergartens AND the MaIN Difficulties}

\subsection{The Promotion of Bilingual Teaching in Chinese Kindergartens}

Preschool students in China are almost the children from 3 years old to 6 years old. They always spend 10 hours a day in their kindergartens. Teachers and children live together, learn together and play together. According to behaviorists, language environment plays a leading role in the reinforcement of language input and providing immediate positive feedbacks. In a second language classroom, children's language skills are developed in various ways, for example, dialogue, singing songs and storytelling. These activities are considered to facilitate second language acquisition a lot since it could help the children learn more words used in our daily life, let them be interested in learning English, encourage them to communicate and make them be willing to exchange their ideas with the teacher and their classmates.

Children could find their interest in different things all the time. They are curious about fresh ideas and fresh items they meet, and then they would like to observe, make inquiries, learn and understand. Learning a second language has many different critical periods, but childhood must be the first early period when children have the big advantage in improving pronunciation and developing language skills. Chinese parents know well about these since they are quite aware of the development of their own child, expecting the child will be one of the exceptional students in their school. And advertisements about bilingual teaching are frequently seen on the two sides of Chinese streets. Their impassioned slogans attract groups of parents to take their child there as if the enrollment means a good start and half of the battle.

\subsection{The Main Difficulties In Chinese Kindergarten Bilingual Education}

Bilingual education has flourished in China these days and certain success has already been achieved. 
A large number of studies show that bilingual education does work in promoting children's cognitive development, improving language skills and their interpersonal relationships. However, lots of problems still exist in China's bilingual teaching practice.

\subsubsection{Lack of comprehensive knowledge of bilingual education}

Even though bilingual teaching is quite popular all around China, parents lack a solid consideration and the teachers lack a comprehensive study of bilingual education. Blindness and arbitrariness exist in the implementation of bilingual teaching, since part of the schools have not realized its real significance for which bilingual education is just one of the ways for them to carry out in order to attract more students and build up the reputation. Child students in big cities have a better chance to engage themselves in bilingual study because they are living in an environment in which English is often used in their daily life., while for students living in small towns or even some medium cities, they could not understand why English is becoming more and more important because English is not a necessary instrument for them to communicate. Thus, most of the parents would not encourage their children to keep continuous study about English, and some of the teachers would use our mother language instead of English so as to let the students understand what they are teaching immediately and easily. Therefore, motivation for English study will soon disappear and knowledge acquirement in bilingual education will be directly discouraged. So the effectiveness of bilingual teaching is a tough task for us to achieve.

\subsubsection{Disqualification of the bilingual teachers}

Most of the Chinese teachers pay more attention to the scores and students' good performances in various tests and examinations and pay less attention to strengthen children's awareness of English language acquisition and the cultivation of their language skills. Besides, some of them choose English education as their major in college just because of the popularity of this profession, so they didn't spend much time training their language skills and learn more relevant theories and methodologies on bilingual teaching. Moreover, child students are quite different from the students in middle schools. They have an unique character to some degree and at the same time, they display different kinds of emotions and have changeable ideas and behaviors. Part of the bilingual teachers don't realize their typical physiological differences and psychological characteristics, as a result, they can not give a well-developed teaching plan in the light of children's specific characters. In addition, some of Chinese language teachers haven't got a standard pronunciation partly because they haven't received normal education before college. Hence Chinglish is frequently heard in Chinese language classroom and this is not a good model for child students to imitate, even though children are very good at imitation, especially in language learning process. Lastly, lack of fund is a big problem for most of the Chinese kindergartens to invite qualified teachers since salary is always given the first priority when teachers are seeking a satisfying job for themselves.

\subsubsection{Cultural diversity in China's different areas and cities}

Bilingual education lacks its inevitability and feasibility in China. Government promotes bilingual teaching, but according to the cultural diversity in our country, it is not an imperative choice for different ethical areas. For instance, in some of the poor districts in Tibet, Yunnan province, Sichuan province and Guizhou province, language learning priority is given to mandarin or their minority language. Consideration of foreign language learning will be taken into account when students begin their middle school study, and kindergarten is a place for children to play with each other and learn social routines. It may also be totally absent even in some ethical villages, not to mention bilingual education. 
4. Suggestions for Solving the Problems in Chinese Kindergarten Bilingual EDUCATION

\subsection{Arousing Awareness of Bilingual Education in China}

At first, the government should lay more emphasis on bilingual education. Encouragement from the government and financial support are the most important precondition. Moreover, kindergarten schools need to call for both parents and teachers to pay more attention to arouse children's awareness of the usefulness of English language in our social life. Supermarket is a good place for parents to encourage their kids to know more English words since bilingual introduction of the products is always given and children will be interested in that. Teachers are the key to guarantee the effectiveness of bilingual teaching. So normal colleges in China should take into consideration offering various training programs for language teachers and developing a single system for professional testing. Regular training must be taken as one of the requirements for all the language teachers in China in order to face the fluctuant challenge and bilingual teaching assessment need to be developed with the support of the country.

\subsection{Creative Use of Bilingual Teaching Materials}

Teachers need to find more interesting teaching materials for bilingual class which may promote children's learning motivation. Materials can be collected from the internet, because there are various choices of learning material and we have easy access to download them. Hundreds of particular books designed for bilingual teaching have already published, for example, LEAPFROG (a series of video displaying for preschool students and primary school students to learn English), All ABROAD READING (books printed by the U.S.A Library of Congress in which cards of pictures and words are designed well for English language beginners), and I CAN READ (books published in America which tell a series of stories about a dog named Biscuit), etc. Teachers should decide themselves which to choose for the bilingual classroom according to children's specific psychological characteristics and their learning style.

Additionally, Chinese teachers should be encouraged to work with foreign teachers when selecting appropriate teaching materials for the children. If necessary, they could find some interesting and popular Chinese fables and legendaries and translate them into English. Since Chinese children are already taught about these stories in family and in Chinese reading classes, they are mostly familiar with them. When reading the English version, they may find it easier to follow in a Chinese context.

\subsection{Continuous Focus on Pleasant Language Environment and Improvement of Teaching Methods}

Pleasant language environment should be established and teachers should be encouraged to develop practical teaching methods according to the present situation. With the development of high technology, multimedia instruction is proposed for strengthening children's learning interest and help creating an enjoyable language environment. English songs and animations are an indispensible part of bilingual teaching which can help the students keep their concentration on English language learning and then they may understand songs and movies better than just read the Chinese caption at the bottom of the screen.

Environment is a key factor in early childhood language learning which can encourage the children to be willing to say and follow. Therefore, vivid pictures and lively activities need to be taken into consideration. Visual images will facilitate classroom teaching if it is closely related to children's life experiences, such as pictures of cartoons, toys and animals and so on. For most Chinese children, their 
learning style is different from foreign child. Generally speaking, they learn for happy hour and have no definite purpose. They prefer simpler target, like to imitate, and could only concentrate for a while during the learning process. So classroom activities should be designed in the light of children's learning characteristics. Since they are curious and energetic, activities like "Move your body" and "Fruit squatting" would be quite popular among kindergarten students, in the first of which children are asked to touch different parts of their own body in order to help them memorize the names of all body parts, and in the second fruit names will be repeated many times as to proceed with the game and children will easily remember those English names meanwhile.

Behaviorists indicate that positive reinforcement encourages children's efforts and facilitate positive language learning while negative feedback will discourage them to try again. To gain positive feedback, yoga is one of the choices if situation is good. It is a type of exercise in which you move your body into various positions to achieve body health or train the consciousness for spiritual tranquility. Although children can not finish every step as the adults do, they may be taught to follow simple steps which are easier to accomplish and gain long-term memory of those English directions teachers give them. More importantly, they will be happy to do that again. This activity is suggested according to the Interactionist View which emphasizes children's effective learning occurs only when this target language is modified to the their own comprehension level.

Last but not the least, encouragement and praise are preferred in kindergarten bilingual classroom teaching. Most of the children are quite sensitive because of their tender age. Thus, teachers should show their respect and listen to them attentively. If they make mistakes in language learning, the teacher had better give positive understanding first, and then try to help them realize the mistake and make corrections later. Negative response will hurt the child and kill their interest gradually.

\section{CONCLUSION}

As the critical period of language acquisition, a series of bilingual education model has been set up in China to help the children learn a foreign language. Considering the feasibility of bilingual education, kindergarten is considered as the first critical field for children to acquire English language in China. This paper discusses the main problems in kindergarten bilingual teaching and suggestions are given in order to improve bilingual education in China. Teachers, students and parents are the three indispensible aspects which are involved in bilingual teaching. Parents should take their responsibility as to help their child learn a new language. Teachers need to make imperative changes while teaching as to make sure language input is available for child learners to understand and process. If children can maintain their interest in English language learning, they will be conscious to participate in various classroom activities and enjoy the process. Finally they will achieve their language learning goals unconsciously. But the decisive factor is how bilingual teaching is handled in schools. Bilingual teaching is being faced with great challenges nowadays, and it is hoped the discussion given above could be helpful and enlightening for further studies.

\section{REFERENCES}

Cook, V. 2000. Second Language Learning and Language Teaching. Beijing: Beijing Foreign Language Teaching and Research Press.

E-Power. On Bilingual Instructions in English Teaching for Children. Retrieved 2016, March 1 from http://www.doc88.com/p-297361922904.html

Eric Lenneberg. 1967. Biological Foundations of Language. New York: John Wiley and Sons.

Jack Richards, John Platt \& Heidi Weber. 1985. Longman Dictionary of Applied Linguistics. Harlow, Essex, England: Longman. 
Liu Jinhua. 2002. The Development of Children Psychology. Shanghai: East China Normal University press.

Liu zhenqian. 2003. A Research Review of Critical Period Hypothesis in Language Acquisition. Contemporary Linguistics, 2.

Montessori, Maria. 1965. The Advanced Montessori Method. Oxford: Clio Press.

Ochoa, R. 1999. Bilingual Education Challenged Again. Hispanic, 10, pp. 12-13.

Peal, E. \& Lambert, W. E. 1962. Relations of Bilingual to Intelligence. Psychological Manor Graphs, 76, p.12.

Sonja Lamut. 1996. Too Noisy. Washington D.C.: U.S.A. Library of Congress.

The study of Bilingual Education in Kindergarten. Retrieved 2016, February 26 from http://www.doc88.com/p-1857103734277.html

Wilder Penfield\& Lamar Roberts. 1959. Speech and Brain Mechanism. Princeton: Princeton University Press.

Zehr, M. A. 2002. Voters Courted in Two States on Bilingual Education. Educational Week, 2, pp. 1-2.

Zhang Minghong. 2001. Language Education for Preschool Students. Shanghai: East China Normal University press. 